\title{
Pembelajaran konsep asidimetri dan stoikiometri menggunakan chemcollective's virtual chemistry laboratory
}

\author{
Rizki Dwi Ningsih ${ }^{1}$, Evelin Natasyah ${ }^{1}$, Sony Ananta ${ }^{1}$, Prima Fitra ${ }^{1}$, Naila Rahmi ${ }^{2}$, \& Riryn \\ Novianty*1
}

${ }^{1}$ Fakultas Matematika dan Ilmu Pengetahuan Alam, Universitas Riau

${ }^{2}$ Fakultas Ilmu Sosial dan Ilmu Politik, Universitas Riau

* rirynnovianty@lecturer.unri.ac.id

\begin{abstract}
Abstrak. Ilmu kimia tidak dapat dipisahkan dengan percobaan di laboratorium sebagai bentuk penambahan pemahaman dan pembuktian teori kimia. Permasalahannya, Praktikum kimia memerlukan anggaran yang sangat besar dan penanganan tinggi untuk pembangunan laboratorium, fasilitas peralatan, bahan-bahan kimia dan tempat penyimpanan. Maka, terdapat metode pembelajaran baru yaitu PenerapanTeknologi Chemcollective's Virtual Chemistry Laboratory dengan mensimulasikan praktikum kimia pada aplikasi computer bernama Virtual Lab/Vlab. Hal ini bertujuan memudahkan pemahaman ilmu kimia melalui simulasi praktikum serta memecahkan solusi keterbatasan atau ketiadaan peralatan laboratorium. Metode yang digunakan adalah tahap persiapan instalasi software di PC dan Laptop kemudian pelatihan mempraktekkan secara langsung materi kimia menggunakan Vlab. Pembelajaran objek praktikum menggunakan Vlab salah satunya Asidimetri dan Stoikiometri. Stoikiometri merupakan ilmu kimia yang mempelajari hubungan kuantitatif antara zat-zat yang terlibat dalam reaksi kimia. Titrasi asidimetri adalah proses penentuan konsentrasi basa dengan menggunakan larutan asam sebagai standar. Pada objek Asidimetri nilai rata-rata Pre Test 54 dan Post Test 70, objek Stoikiometri Pre Test 80 dan Post Test 81. Hasil Post Test yang signifikan dibandingkanPre Test padapelatihan di SMAN 1 Bungaraya Siak ini menunjukkan metode Vlab dapat meningkatan pemahaman siswa terhadap konsep kimia, dan disimpulkan Vlab sangat baik untuk diperkenalkan, dipelajari dan diterapkan lebih lanjut di berbagai sekolah.
\end{abstract}

Kata kunci: asidimetri; laboratorium; simulasi; stoikiometri; vlab

\begin{abstract}
Chemistry cannot be separated from laboratory experiments as a form of increasing understanding and proof of chemical theory. The problem is that chemical practices require a very large budget and high handling facilities, equipment facilities, chemicals and storage facilities. So there is a new learning method that uses Chemcollective's Virtual Chemistry Laboratory Technology Application by simulating a chemical lab in a computer application called Virtual Lab / Vlab. This is intended to facilitate the understanding of chemistry through practical simulation and solving solutions for the limitations of laboratory equipment. The method used is the stage of software installation and training to practice the chemicals with Vlab. Learning practicum objects with Vlab is one of them is Acidimetry and Stoichiometry. Stoichiometry is a chemistry that studies quantitative relationships between substances involved in chemical reactions. Acidimetric titration is the process of determining the concentration of bases using acid solutions as a standard. On Acidimetri Pre Test 54 and Post Test 70, object Stoichiometry Pre Test 80 and Post Test 81. The significant results of Post Test versus Pre Test in training at SMAN 1 BungarayaSiak have shown that the Vlab method can improve students' understanding of the concept chemistry. and it was concluded that the Vlab was very good for further introduction, study and application at different schools.
\end{abstract}

Keywords: acidimetry; laboratory; simulation; stoichiometry; vlab

To cite this article: Ningsih, R. D., E. Natasyah, S. Ananta, P. Fitra, N. Rahmi, \& R. Novianty. 2019. Pembelajaran konsep asidimetri dan stoikiometri menggunakan chemcollective's virtual chemistry laboratory. Unri Conference Series: Community Engagement 1: 527-535 https://doi.org/10.31258/unricsce.1.527-535

(C) 2019 Authors

Peer-review under responsibility of the organizing committee of Seminar Nasional Pemberdayaan Masyarakat 2019 


\section{PENDAHULUAN}

Kimia merupakan salah satu mata pelajaran sains yang penting seiring dengan berkembangnya ilmu pengetahuan dan teknologi saat ini. Fakta di lapangan menunjukkan bahwa pelajaran kimia dianggap sebagai pelajaran yang sulit dan menjadi momok bagi peserta didik. Ilmu kimia lebih sulit dipelajari dibandingkan bidang ilmu lainnya karena kimia merupakan ilmu abstrak, berjenjang dan kompleks (Chang, 2010).

Ilmu kimia pada hakikatnya adalah ilmu yang bersifat eksperimental, maka percobaan adalah salah satu langkah dalam pengembangan ilmu kimia. Pemahaman ilmu kimia di tingkat SMA akan lebih baik dengan praktikum karena dapat sekaligus membuktikan teori yang mereka pelajari. Kegiatan praktikum adalah salah satu cara untuk membantu siswa/siswi untuk memahami materi yang mereka terima di kelas, sehingga materi lebih mudah dipahami sekaligus dapat menarik minat siswa/siswi untuk lebih mempelajari ilmu kimia (Sarah, 2013).

Praktikum dalam bidang sains memerlukan anggaran yang sangat besar, karena selain untuk pembangunan laboratorium beserta fasilitasnya, juga memerlukan tempat penyimpanan yang aman agar bahan kimia tidak mudah rusak dan tidak membahayakan orang lain. Untuk menjaga laboratorium dapat berfungsi sebagaiman mestinya maka sebuah laboratorium memerlukan tenaga administrasi dan teknisi (Silawati, 2006).

Simulasi pada dasarnya merupakan salah satu model alternatif yang sederhana dan murah. Program simulasi dengan bantuan komputer mencoba untuk menyamai proses dinamis dalam dunia nyata. Simulasi memanfaatkan program (software) komputer yang difungsikan untuk meniru perilaku sistem nyata (realitas) tertentu (Handayani dkk, 2018). Sebagai metode mengajar, simulasi dapat diartikan cara penyajian pengalaman belajar dengan menggunakan situasi tiruan untuk memahami tentang konsep, prinsip, atau keterampilan tertentu. Simulasi dapat digunakan sebagai metode mengajar dengan asumsi tidak semua proses pembelajaran dapat dilakukan secara langsung pada objek yang sebenarnya. Demikian juga untuk mengembangkan pemahaman dan penghayatan terhadap suatu peristiwa, penggunaan simulasi akan sangat bermanfaat (Suyanti, 2010).

Mengembangkan dan melaksanakan aktivitas praktikum sangat penting bagi perkembangan siswa, sebagaimana yang sering diungkapkan, "Saya mendengar, saya lupa; saya melihat, saya ingat; dan saya mengerjakan, saya mengerti". Keunggulan dari metode simulasi untuk pembelajaran diantaranya:

1. Dapat dijadikan sebagia bekal bagi siswa dalam menghadapi situasi yang sebenarnya kelak, baik dalam kehidupan keluarga, masyarakat, maupun menghadapi dunia kerja.

2. Dapat mengembangkan kreativitas siswa.

3. Dapat memupuk keberanian dan percaya diri siswa.

Chemcollective (www.chemcollective.org) merupakan digital library yang dapat diakses secara online. Chemcollective didesain untuk memberikan pengetahuan kimia secara umum yang di dalamnya terdapat berbagai macam simulasi kimia yang lebih menarik dibandingkan buku. Di dalam www.chemcollective.org terdapat "Virtual Lab (vlab) software" yang menyediakan alat dan bahan kimia yang dapat digunakan untuk bereksperimen. Chemcollective's Virtual Chemistry Laboratory akan meningkatkan pengetahuan dan pemahaman siswa terhadap teori kimia karena diintegrasikan dengan praktikum berbasis simulasi (Yaron $e t$ al, 2010).

Tujuan diadakannya pengabdian ini tentunya untuk memperkenalkan praktikum kimia berbasis simulasi menggunakan Chemcollective's Virtual Chemistry Laboratory kepada guru kimia dan juga siswa SMAN 1 Bungaraya Siak. Selain itu juga untuk meningkatkan pemahaman dan ketertarikan siswa terhadap pelajaran kimia.

\section{Masalah}

SMAN 1 Bungaraya Kabupaten Siak merupakan salah satu sekolah negeri di Provinsi Riau yang memberikan mata pelajaran Kimia kepada siswa/siswi dalam bentuk teori. Pemahaman materi kimia di dalam kelas sayangnya tidak dibarengi dengan pengalaman praktikum. Hal ini disebabkan karena SMA 1 Bungaraya tidak memaksimalkan penggunaan laboratorium yang ada. Sebenarnya sekolah ini telah memiliki peralatan praktikum sederhana dan zat-zat kimia, namun karena keterbatasan tempat maka laboratorium digunakan sebagai ruangan belajar. Ironisnya, pembelajaran praktek kimia di laboratorium hanya dilakukan satu kali dalam setahun. Kendala yang berkaitan dengan dengan praktikum kimia ini tentu membuat siswa/siswi sulit meningkatkan pemahaman tentang materi-materi kimia. Untuk itu perlu dicari solusi untuk menunjang pembelajaran kimia dengan cara menggunakan gadget berupa laptop. Umumnya guru kimia dan siswa/siswi SMAN 1 Bungaraya telah memiliki laptop yang dapat dioptimalkan penggunaannya dengan melaksanakan 
praktikum berbasis simulasi. Sehingga guru dapat lebih meningkatkan performanya dalam menjelaskan materi kimia dan bagi siswa/siswi dapat mengembangkan daya imajinasinya terkait dengan teori kimia yang telah mereka pelajari.

\section{METODE}

Metode yang digunakan dalam program pengabdian ini adalah metode simulasi berbasis teknologi. Dilakukannya simulasi praktikum berbasis teknologi ini sebagai solusi dari keterbatasan alat dan bahan yang ada di SMAN 1 Bungaraya Siak, serta laboratorium yang ada digunakan sebagai ruangan belajar, sehingga tidak dapat berfungsi sebagaimana mestinya. Metode pendekatan pada program ini menggunakan metode transfer ilmu dari mahasiswa sebagai tutor kepada siswa/siswi. Indikator keberhasilan siswa dapat dilihat dari hasil Pre Test dan Post Test yang diberikan kepada siswa/siswi SMAN 1 Bungaraya melalui Google Form. Program ini diberikan kepada siswa/siswi kelas X dan XI.

Langkah-langkah dalam program ini, yaitu:

1. Menetapkan SMAN 1 Bungaraya Siak sebagai sekolah sasaran dengan survey lokasi pada 10 April 2019.

2. Merancang Buku Pegasus dan Video tutorial yang diberikan kepada pihak sekolah.

3. Melakukan pelatihan dan Evaluasi di Ruangan Multimedia SMA N 1 Bungaraya Siak, dengan waktu pelatihan 180 menit

4. Metode keberlanjutan kegiatan ini berupa kerjasama dengan mitra melalui guru dan OSIS SMAN 1 Bungaraya melalui teknik pemberian/pengajaran Vlab oleh guru kimia dan siswa/siswi terbaik sebagai bentuk keberlanjutan kegiatan untuk memperkuat teknik pelatihan dengan.

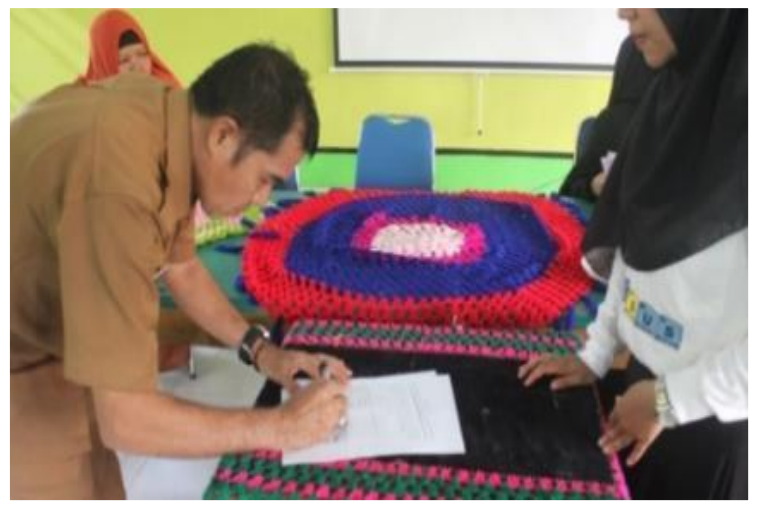

Gambar 1. Penandatanganan MoU

Adapun teknik-teknik metode pengabdian yang dilakukan adalah:

\section{Teknik Pengumpulan Data}

Teknik pengumpulan data akan dilaksanakan sebagai berikut:

a. Pre Test, yaitu, untuk mengetahui seberapa besar pengetahuan mereka tentang teori ilmu kimia dasar termasuk teori tentang praktikum.

b. Post Test, yaitu membagikan kuesioner kembali yang berisi soal-soal tentang pengetahuan setelah sosialisasi.

Pada teknik pengolahan dan analisis data, Tim Pegasus akan menyusun kuesioner yang akan diisi oleh siswa untuk Pre Test maupun Post Test. Lalu hasil kuesioner yang telah diisi oleh siswa, akan dikembalikan lagi kepada tim pengabdian Pegasus untuk menganalisis seberapa besar pengetahuan siswa dan untuk mengetahui tingkat pemahaman siswa tentang simulasi menggunakan Chemcollective's Virtual Chemistry Laboratory setelah dijelaskan oleh tim Pegasus. Sehingga dari kuesioner, akan didapatkan hasil dari kegiatan yang telah dilaksanakan.

\section{Teknik Analisis Pelatihan}

Analisis pelaksanaan pelatihan pengabdian yang dilakukan yaitu teknik Pre-test, penyampaian materi, mandiri, diskusi, Post-test. 
a. Pre-test, Untuk mengetahui seberapa besar pengetahuan siswa/siswi tentang teori ilmu kimia dasar termasuk teori tentang praktikum.

b. Penyampaian materi, penjelasan materi kimia secara teori dan praktik dengan judul Alkalimetri, Kesetimbangan Kimia, Asidimetri dan Stoikiometri.

c. Mandiri, memberikan kesempatan kepada peserta siswa/siswi untuk berlatih mandiri penggunaan aplikasi Vlab terhadap penyampaian materi yang dijelaskan sebelumnya.

d. Diskusi, suatu proses pemecahan masalah terhadap penjelasan materi.

e. Post-test, Untuk mengetahui siswa/siswi tentang pemahaman materi setelah sosialisasi.

Dengan tahapan pelatihan yang dilakukan yaitu:

1. Penetapan peserta kegiatan yang akan dilibatkan dalam pelatihan yaitu siswa/siswi kelas X dan XI.

2. Pemberian buku ajar Pegasus yang telah dirancang sebanyak 55 buah dan video tutorial Vlab kepada pihak sekolah

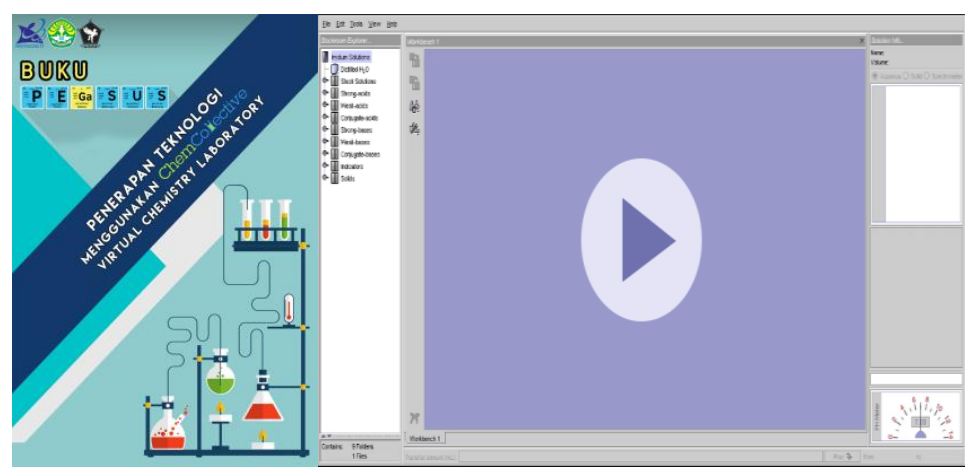

Gambar 2. Buku Ajar Pegasus dan Video Tutorial Vlab

3. Menyiapkan PC dan laptop sebagai media simulasi

4. Mempersiapakan aplikasi Vlab di media simulasi:

a. Mendownload Chemcollective's Virtual Chemistry Laboratory di http://chemcollective.org/assets/modules/activities/Vlab/download/Vlab.2.1.0.zip

b. Mendownload java offline installer (jre-8u121-windows-i586.exe) : www.java.com/en/download/windows_offline.jsp

c. Menjalankan instalasi java dengan mengeksekusi file offline java installer yang telah didownload

d. Ekstrak file Vlab.2.1.0.zip

e. Mencopy file offline java installer dan Vlab ke flashdisk.

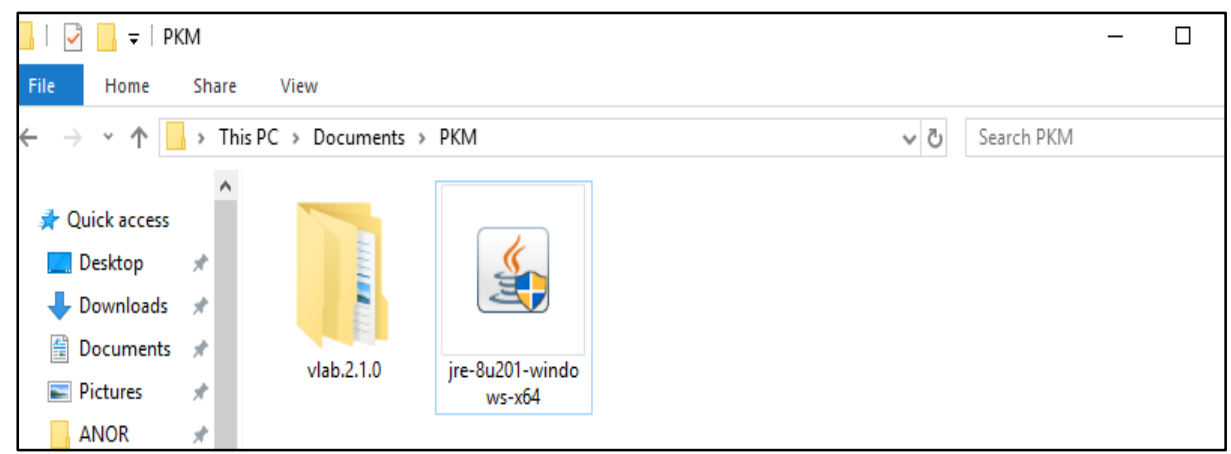

Gambar 3. Installer Vlab

5. Menetapkan objek praktikum yang dipraktekkan di Vlab

6. Pelaksanaan Pre Test menggunakan Google Form.

7. Pemberian materi pelajaran kimia serta metode praktikum kimia berbasis simulasi menggunakan Chemcollective's Virtual Chemistry Laboratory.

8. Latihan dan diskusi

9. Pelaksanaan Post Test menggunakan Google Form.

10. Pengisian Kuesioner menggunakan Google Form. 


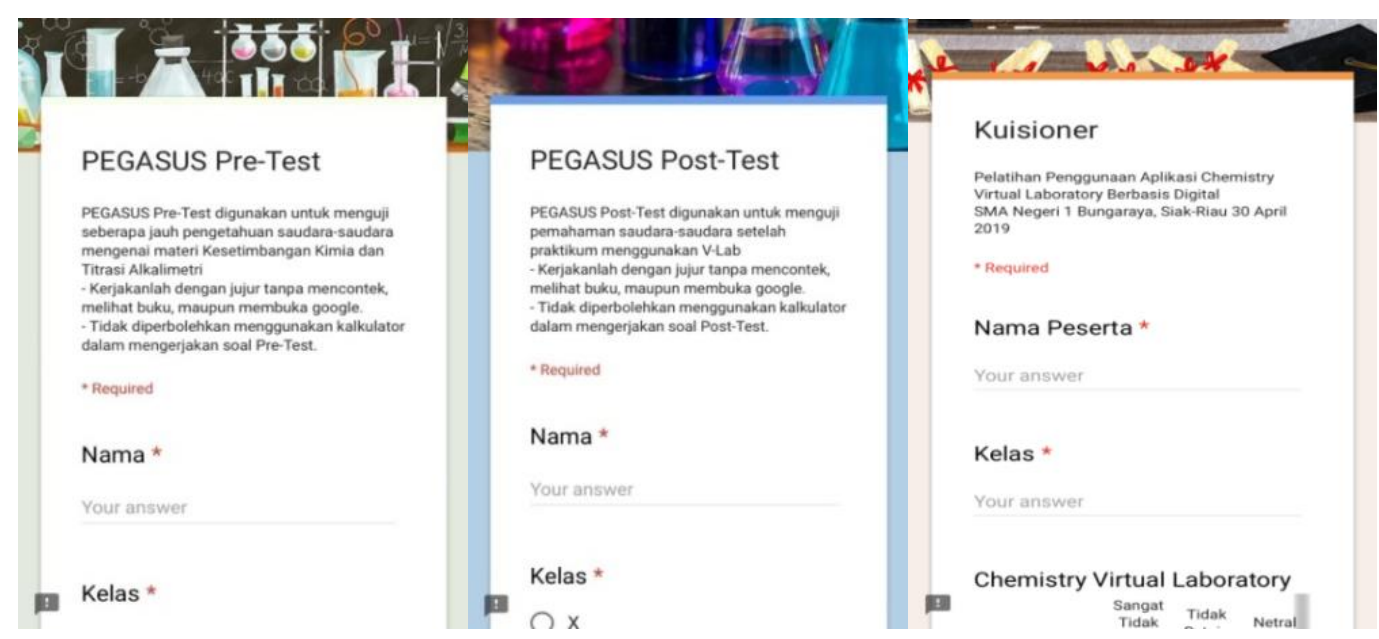

Gambar 4. Pre-test, Post-test dan Kuesioner

11. Pemilihan siswa/siswi terbaik.

\section{PEMBAHASAN}

Pengabdian yang dilakukan merupakan metode atau model pembelajaran baru praktikum kimia berbasis simulasi. Kegiatan ini merupakan Penerapan Teknologi Menggunakan Chemcollective's Virtual Chemistry Laboratory di SMAN 1 Bungaraya telah dilakukan 5 kali dengan 4 pelatihan materi objek. Dalam hal ini objek Asidimetri dan Stoikiometri merupakan pelaksanaan pengabdian ke 4 dan 5 yang dilakukan pada Selasa 21 mei 2019 dan Selasa 18 juni 2019 yang diikuti oleh siswa/siswi Kelas X dan XI. Kegiatan ini diawali dengan pembukaan yaitu kata sambutan disertai pemberian luaran kegiatan kepada pihak sekolah berupa Buku Ajar Pegasus dan Video tutorial yang bertujuan untuk menunjang pemahaman dan pembelajaran siswa/siswi terhadap simulasi praktikum menggunakan Vlab.

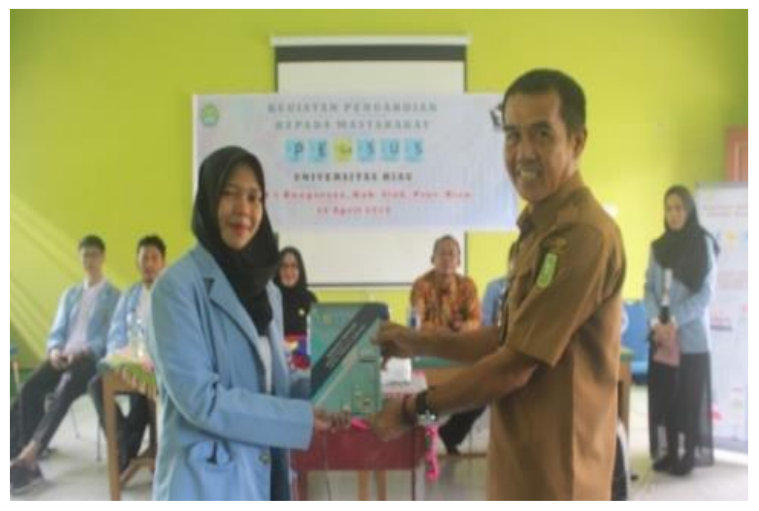

Gambar 5. Pemberian Buku Ajar Pegasus

Adapun tahap-tahap kegiatan yang dilakukan adalah sebagai berikut:

\section{Pre Test}

Pre Test adalah suatu metode awal yang digunakan untuk mengetahui sejauh mana pengetahuan dan pemahaman siswa/siswi terhadap pelajaran Kimia dan praktek Kimia. Adapun Pre Test ini dilakukan menggunakan Google Form yang juga merupakan salah satu aplikasi modern yang praktis dengan menggunakan jaringan internet agar dapat diakses, dan sebagai salah satu upaya untuk mencintai lingkungan dengan mengurangi penggunaan kertas. Pre Test ini berisi 10 soal dasar-dasar Kimia sebelum diperkenalkannya teknologi Vlab kepada siswa/siswi. 


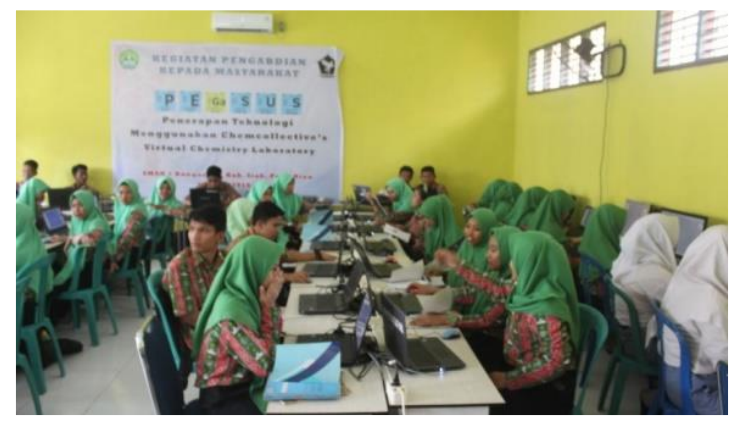

Gambar 6. Kegiatan awal siswa/siswi melakukan Pre Test

\section{Proses Pengenalan dan Pembelajaran}

Metode selanjutnya adalah pengenalan aplikasi Vlab. Dalam hal ini siswa/siswi terlebih dahulu dikenalkan alat-alat praktikum serta cara penggunaannya langsung pada Vlab yang dijelaskan langsung oleh pemateri. Proses pembelajaran kimia tentunya akan lebih mudah dipahami jika diiringi dengan praktek, hal ini tentunya tidak lepas dari proses pembelajaran kimia untuk melihat hasil nyata dari pemahaman kimia yang telah dipelajari di kelas.

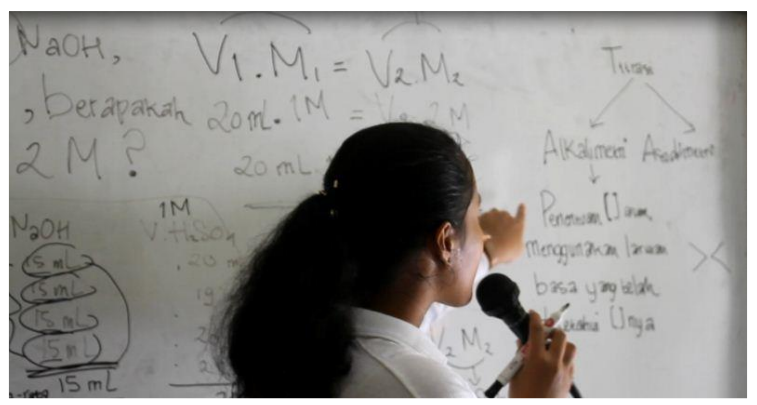

Gambar 7. Penjelasan Materi

Materi-materi praktikum dalam proses pembelajaran di aplikasikan langsung menggunakan Vlab atau Chemcollective's Virtual Chemistry Laboratory yang sebelumnya telah dilakukan penginstallan ke media elektronik (komputer dan laptop). Adapun materi pelatihan adalah sebagai berikut:

1. Asidimetri

Titrasi asidimetri adalah suatu proses titrasi untuk penentuan konsentrasi suatu basa dengan menggunakan larutan asam sebagai standar. Reaksi yang terjadi pada prinsipnya adalah reaksi netralisasi, yaitu pembentukan garam dan $\mathrm{H}_{2} \mathrm{O}$ netral $(\mathrm{pH}$ 7) hasil reaksi antara lain $\mathrm{H}+$ dari suatu asam dan $\mathrm{OH}$ - dari suatu basa. Reaksi berlangsung secara stoikiometri apabila mg pentitrasi sama dengan mg titran, saat ini disebut dengan titik ekuivalen. Dalam praktek kondisi ini tidak bisa dilihat secara visual tetapi dapat dilihat dengan bantuan indikator (asam-basa) yang mempunyai warna yang spesifik pada $\mathrm{pH}$ tertentu. Seperti indikator Metil Orange akan berwarna orange pada $\mathrm{pH} 3,1-4,4$, saat tercapainya perubahan warna pada titran disebut dengan titik akhir titrasi (Ningsih, dkk., 2019).

2. Stoikiometri

Stoikiometri (stoi-kee-ah-met-tree) merupakan bidang dalam ilmu kimia yang menyangkut hubungan kuantitatif antara zat-zat yang terlibat dalam reaksi kimia, baik sebagai pereaksi maupun sebagai hasil reaksi. Stoikiometri juga menyangkut perbandingan atom antar unsur-unsur dalam suatu rumus kimia, misalnya perbandingan atom $\mathrm{H}$ dan atom $\mathrm{O}$ dalam molekul $\mathrm{H} 2 \mathrm{O}$. Kata stoikiometri berasal dari bahasa Yunani yaitu stoicheon yang artinya unsur dan metron yang berarti mengukur. Seorang ahli Kimia Perancis, Jeremias Benjamin Richter (1762-1807) adalah orang yang pertama kali meletakkan prinsipprinsip dasar stoikiometri. Menurutnya stoikiometri adalah ilmu tentang pengukuran perbandingan kuantitatif atau pengukuran perbandingan antar unsur kimia yang satu dengan yang lain (Ningsih, dkk., 2019). 
Post Test adalah metode lanjutan untuk melihat sejauh mana keberhasilan dari proses pemahaman penerapan teknologi menggunakan Chemcollective's Virtual Chemistry Laboratory. Metode ini dilakukan sama dengan Pre Test yaitu melalui Google Form. Hasil yang diperoleh menunjukkan adanya peningkatan yang signifikan dari hasil penilaian yang didapatkan, yaitu dengan 80-90 persen.

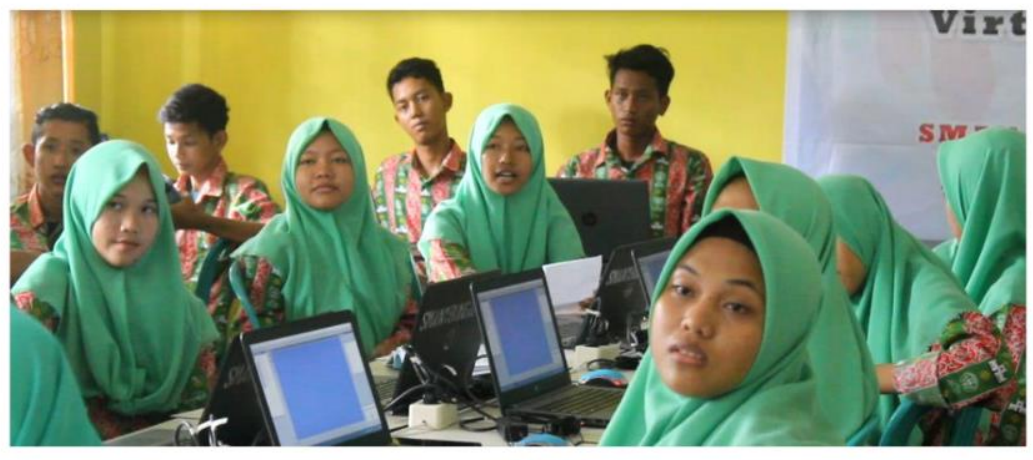

Gambar 8. Pemberian hasil nilai Post Test

Berikut tampilan grafik hasil kegiatan berdasarkan nilai Pre Test dan Post Test yang didapatkan oleh siswa/siswi:

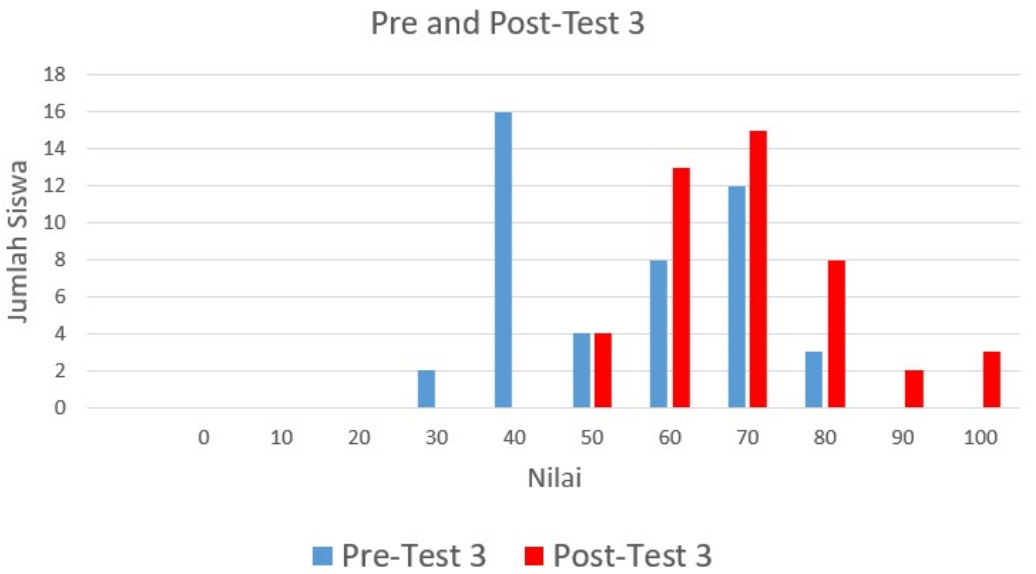

Gambar 9. Hasil Pre Test dan Post Test Objek Asidimetri

Berdasarkan Gambar 9 yaitu pada pelatihan pengabdian ke 4 dengan objek materi Asidimetri. Hasil Pre Test siswa/siswi tidak ada yang mendapat nilai dibawah 30 dan dengan rata-rata 54 serta meningkat secara signifikan pada hasil Post Test dengan rata-rata 70.

Berdasarkan grafik nilai pada Gambar 10 yaitu pada pelatihan selanjutnya dengan objek materi Stoikiometri hasil Pre Test yang didapatkan yaitu rata-rata 80 dan Post Test 81. Pada pelatihan yang ke 5 ini sudah terlihat siswa/siswi sudah mulai terbiasa dan memahami pembelajaran praktikum kimia menggunakan Vlab dengan dibuktikan terlihat pada hasil Pre Test dan Post Test nilai berada diatas 60 dengan rata-ratanya yang tidak jauh berbeda.

Hal ini menunjukkan bahwa metode pembelajaran dengan penerapan teknologi menggunakan Chemcollective's Virtual Chemistry Laboratory merupakan proses pembelajaran kreatif, inovatif, dan edukatif yang lebih mudah dari segi penggunaannya dan mampu meningkatkan pemahaman siswa/siswi terhadap kimia. Keunggulan dari Vlab ini adalah belum adanya sosialisasi bahkan penggunaannya di Indonesia dan keunggulan aplikasi Vlab ini yaitu terdapat berbagai macam objek praktikum yang dapat dilakukan, maka luaran atau kreatifitas yang di tunjukkan yaitu membuat Buku Ajar Pegasus yang ber-ISBN dan Video Tutorial yang merupakan hasil karya Tim dan bahkan kegiatan telah di publikasi diberbagai media massa yaitu media cetak (Pekanbaru pos), online (riaupos.co) dan televisi (RTv) serta Publikasi artikel ilmiah di jurnal nasional (Jurnal Pegabdian Untuk Mu negeRI), hanya saja kesulitan atau persoalan pelaksanaan kegiatan yaitu pada 
jadwal pelatihan, dimana pelatihan yang kami lakukan sedikit tertunda akibat bentrok nya dengan jadwal libur sekolah.

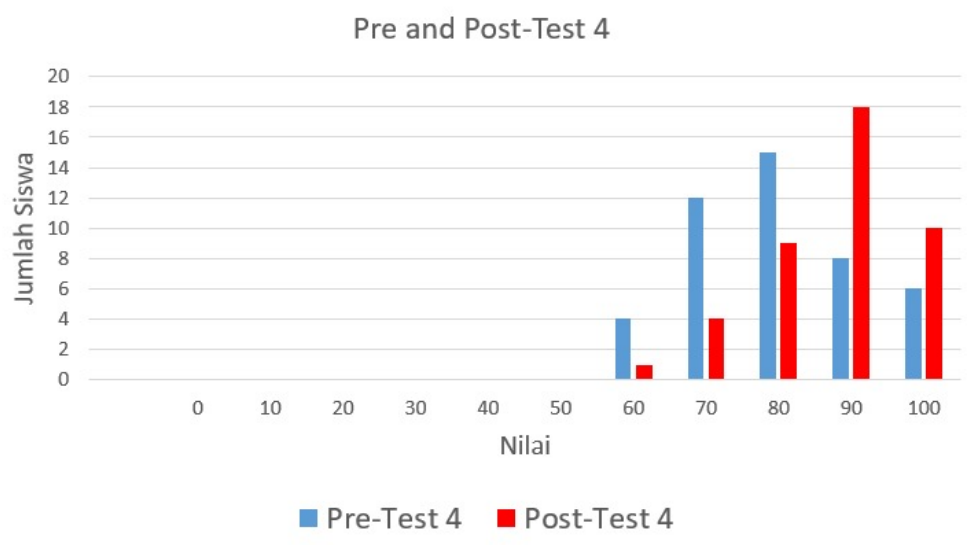

Gambar 10. Hasil Pre Test dan Post Test Objek Stoikiometri

\section{KESIMPULAN}

Kesimpulan dari pelaksanaan program "Pegasus" ini bahwasanya metode ini dapat meningkatkan pemahaman siswa/siswi terhadap suatu pokok bahasan pembelajaran kimia serta memecahkan solusi keterbatasan atau ketiadaan peralatan laboratorium melalui praktikum berbasis simulasi Chemcollective's Virtual Chemistry Laboratory. Hal ini dapat dilihat dari hasil Pre Test dan Post Test, yaitu dari hasil Post Test menunjukkan adanya peningkatan nilai yang diraih oleh siswa, bahkan pada pelatihan yang ke 5 siswa/siswi mendapatkan nilai rata-rata Pre Test dan Post Test yang tidak jauh berbeda, lain halnya saat pelaksanaan pelatihan pertama dan kedua. Hal ini menujukkan bahwa metode pembelajaran dengan penerapan teknologi menggunakan Chemcollective's Virtual Chemistry Laboratory telah mampu meningkatkan pemahaman siswa/siswi terhadap ilmu kimia melalui eksperimetal praktikum melalui simulasi dan memenuhi target keberhasilan kegiatan dan luaran kegiatan $85 \%$.

Keuntungan metode simulasi yang dilakukan disamping aksesnya yang mudah dan fleksibel, juga metode ini aman serta tidak memerlukan biaya yang mahal untuk melakukan praktikum. Proses pembelajaran menjadi lebih menarik, interaktif, efektif dan berkualitas. Sehingga dapat disimpulkan Vlab ini sangat baik untuk diperkenalkan, dipelajari dan diterapkan lebih lanjut di berbagai sekolah dengan manfaat yang luar biasa dalam membantu guru memberikan metode pembelajaran baru dalam menambah pemahaman siswa yang nantiny a akan meningkatkan mutu dan prestasi sekolah dan pendidikan. Diakhir kegiatan, diberikan Kuesioner melalui Google Form mengenai pendapat siswa terhadap metode Vlab ini. Hasil kuesioner menunjukkan bahwasanya siswa/siswi sangat setuju dan setuju pembelajaran dengan penerapan teknologi seperti ini, karena sangat membantu dan bagus untuk dikembangkan.

\section{UCAPAN TERIMA KASIH}

Kami mengucapkan terima kasih kepada Kementerian Riset, Teknologi, dan Pendidikan Tinggi yang telah memberikan hibah pada Program Kreativitas Mahasiswa bidang Pengabdian kepada Masyarakat, sehingga program pengabdian dapat terlaksana dengan baik. Kepada Rektor dan Wakil Rektor bidang Kemahasiswaan Universitas Riau yang telah membantu serta memfasilitasi demi kelancaran progam ini. Kepada dosen pendamping Ibunda Riryn Novianty, M.Si yang telah membimbing kami mulai dari proses pembuatan proposal dan hingga saat ini yang tak kenal lelah untuk selalu membimbing kami. Kepala Sekolah serta staf jajaran SMAN 1 Bungaraya Kabupaten Siak, dan juga siswa/siswi yang sangat antusias terhadapa program yang kami lakukan. 


\section{DAFTAR PUSTAKA}

Chang, Y. H., \& C. Y. Chang. 2010. Trends of science education research; an automatic content analysis. Journal of Science Education and Technology 19(4): 315-331.

Handayani, D. N. S., P. Yudhiakto, \& Suparwoto. 2018. Simulasi Visualisasi Gelombang 2d dan 3d pada Membran Lingkaran dengan Software Scilah. Yogyakarta: UAD Press.

Ningsih, R. D., N. Evelin, A. Sony, R. Naila, F. W. A. Prima, \& N. Riryn. 2019. Penerapan Teknologi Menggunakan Chemcollective's Virtual Chemistry Laboratory. Pekanbaru: UNRI Press.

Sarah, B. B. 2013. Review of Teaching Chemistry-A Studybook: A Practical Guide and Textbook for Student Teachers, Teacher Trainees and Teachers. J. Chem. Educ 90(5): 532-533.

Silawati, T. 2006. Microscience Experience: Sebuah Alternatif Praktikum bagi Mahasiswa Pendidikan Jarak Jauh. Jurnal Pendidikan Terbuka dan Jarak Jauh 7(2): 113-120. http://simpen.lppm.ut.ac.id/htmpublikasi/silawati.pdf

Suyanti, R. D. 2010. Strategi Pembelajaran Kimia. Yogyakarta: Graha Ilmu.

Yaron, D., M. Carabinos, D. Lange, J. G. Greeno, \& G. Leinhard. 2010. The Chemcollective Virtual Labs for Introductory Chemistry Cources. Essay on Science and Society 328(5978): 584-585. 